\title{
AVALIAÇÃO DA ENERGIA DE IMPACTO CHARPY E IZOD ALCANÇADO EM COMPÓSITOS POLIMÉRICOS REFORÇADOS COM FIBRAS MALVA*
}

\section{Resumo}

\author{
Jean Igor Margem ${ }^{1}$ \\ Carolina Gomes Dias Ribeiro ${ }^{2}$ \\ Marina Rangel Margem ${ }^{3}$ \\ Ygor Macabu de Moraes $^{2}$ \\ Frederico Muylaert Margem ${ }^{4}$ \\ Sergio Neves Monteiro ${ }^{5}$
}

Materiais sustentáveis estão sendo investigados para substituir os materiais sintéticos, os compósitos com matriz polimérica têm sido aplicados em componentes, tais como capacetes e blindagem para os quais a resistência em um requisito importante. $O$ presente trabalho avalia a classificação energética de impacto Charpy e Izod da matriz de epóxi compósitos DGEBA / TETA, reforçado com até $30 \%$ em volume de fibras de malva contínuas e alinhadas (Urena Lobata, L). Os testes de impacto foram realizados em amostras padronizadas em matriz de epoxi obtidas por aplicação de pressão em molde com cura a temperatura ambiente por 24 horas. Os resultados mostraram aumento significativo da energia de impacto com a fracção de fibras incorporadas de malva. A superfície de fratura foi analisada por microscopia eletrônica de varredura, SEM. O desempenho das amostras incorporados com $30 \%$ de fibras, sofreu apenas ruptura parcial devido a dificuldades impostas ao quebrar-se as fibras, e, consequentemente, a natureza dos quais fendas tendem a propagar na interface entre a matriz de fibra / resina epóxi, o que ajuda a absorver a energia do impacto.

Palavras-chave: Malva; Compósitos; Matriz epóxi; Impacto Charpy; Impacto Izod; Ductilidade.

\section{IMPACT ENERGY RATING CHARPY AND IZOD REACHED IN POLYMER COMPOSITES INCORPORATED WITH MALVA FIBERS}

\begin{abstract}
Environmentally friendly materials are currently being investigated to replace synthetic materials, the polymer matrix composites have been applied in components such as helmets and shielding for which toughness in a major requirement. The present work evaluates the Charpy and Izod impact energy rating of epoxy matrix composites DGEBA/TETA, reinforced with up to $30 \%$ in volume of continuous and aligned malva fibers(Urena Lobata,L).The impact tests were performed on standard specimens obtained by pressing mold cure epoxy after 24 hours. The results showed significant increase in impact energy with the fraction of incorporated of malva fibers. The fracture surface was analyzed by scanning electron microscopy, SEM. The performance of the samples incorporated with $30 \%$ of fibers, suffered only partial rupture due to difficulty imposed by breaking the fibers themselves, and accordingly, the nature of which cracks tend to propagate at the interface between fiber/epoxy matrix, which helps to absorb impact energy.

Keywords: Malva; Composite; Epoxy matrix; Charpy impact; Izod impact; Notch toughness.

1 Doctor In Materials Engineering, Associate Professor, Department of Mechanical Engineering, ISECENSA, Campos dos Goytacazes, Rio de Janeiro, Brasil.

2 Graduating In Metallurgical Engineering and Materials, Student, Department of Materials, State University of the Northen Rio de Janeiro, Campos dos Goytacazes, Rio de Janeiro, Brasil.

3 Graduated In Chemical Engineering, Department of Chemical Engineering, Federal University of the Rio de Janeiro, Rio de Janeiro, Brazil.

4 Doctor In Materials Engineering, Associate Professor, Department of Electrical Engineering, Faculdade Redentor, Itaperuna, Rio de Janeiro, Brasil.

5 Phd In Materials Engineering, Emeritus Professor, Depart. of Materials, IME, Rio de Janeiro, RJ, Brazil.
\end{abstract}




\section{INTRODUCTION}

The modern industrial materials require more sustainable and environmentally friendly alternatives, this trend has increased the attention on reinforced polymer composites with lignocellulosic fibers, such as the malva Fibers (Urena Lobata, L). Those fibers composites present characteristics like a high impact absorption by the composite structure. This work aim to analyze the resistance to impacts of composites produced with epoxy matrix and amounts ranging from $0 \%$ to $30 \%$ in volume of continuous and aligned malva fibers. The objective is to analyze how the Charpy and Izod impact resistance improves with the inclusion of more and more fibers, up to $30 \%$ in volume. The results showed a remarkable increase in the notch toughness with the amount of incorporated malva fibers. This can be attributed to a preferential debonding of the fiber/matrix interface, which contributes to an elevated absorbed energy. Polymer composites reinforced with natural fibers, mainly those lignocellulosic obtained from plants, have been subject to extensive research works ${ }^{1-}$ 5. Environmental, economical, societal and technical advantages of these composites are motivating their substitution for similar polymer composites reinforced with synthetic fibers. In particular, R\&D efforts have been conducted aiming to replace glass fibers composites that are comparatively more abrasive to equipments, nonrecyclable, more expensive, heavier and toxic ${ }^{6}$.

Among the many lignocellulosic fiber composites being investigated, those fabricated with malva fiber, ramie, coco, curaua, bamboo and others fibers longitudinally cut from the culm, still need information to support possible industrial applications. Several works, however, have been dedicated to those fibers as possible reinforcement of polymer composites. The figure 1 show a tipical plantation of Malva in the Amazonas State and Pará.

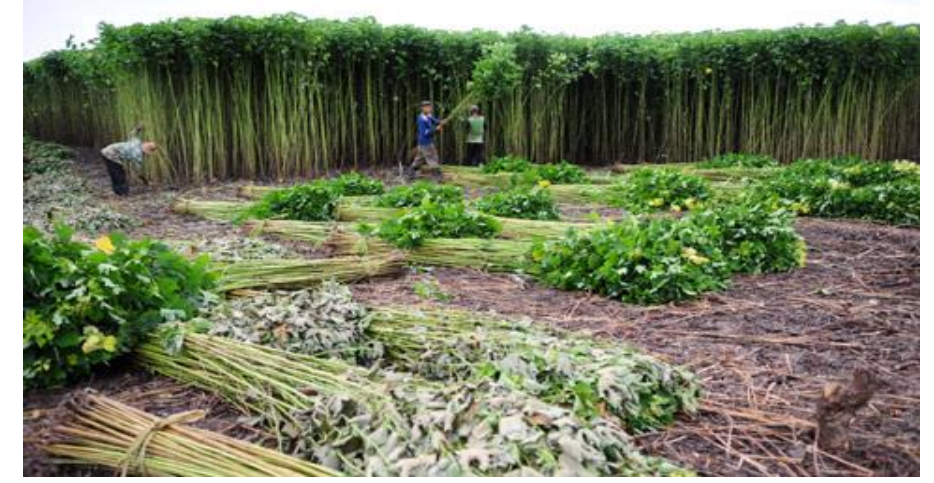

Figure 1. A plantation of Malva fibers

In spite of existing works on the properties of those fibers composites separated, the comparison of impact energy, between malva fibers reinforced in polymeric composites has yet to be evaluated. Therefore, the objective the present work was access energy of impact between charpy test and Izod with epoxy composites reinforced with different amounts malva fibers ${ }^{7-17}$.

\section{EXPERIMENTAL PROCEDURE}

The malva fiber was obtained from Companhia Castanhal Sul, a firm that commercializes natural fibers cultivated in the north region of Brazil. 
In order to produce composites with properties that are acceptable for industrial applications, the malva fibers were randomly selected to serve as reinforcement to a epoxy matrix. These fibers, with an average diameter of $0.065 \mathrm{~mm}$, were laid down inside steel rectangular molds with distinct volume fractions were mixed in amounts of $0,10,20$ and $30 \%$ in volume with epoxy resin type diglycidyl ether of the bisphenol-A (DGEBA) with a DER of $374 \mathrm{~g} / \mathrm{mol}$ and an equivalent weight of 187.3 g/equiv. with triethylene tetramine (TETA), as hardener, in stoichiometric ratio corresponding to phr 13. Both DGEBA resin and TETA hardener were supplied by the DOW Chemical Co.

The fibers were maintained aligned along the length dimension in the dog bone shape composites. The still fluid mixture was poured onto the fibers inside a steel mold and allowed to cure at room temperature (RT) for 24 hours. Ten specimens were prepared for each volume fraction and each fiber kind. The fibers were continuously aligned along the length of the mold. The still fluid epoxy resin was poured onto the fibers and pressured in the mold up to 2 tons, creating the composites plates for each volume fraction. The already processed composites plates were allowed to undergo an initial cure at room temperature for 24 hours.

Afterwards, a post-cure was conducted at $60^{\circ} \mathrm{C}$ for 4 hours. For each composite plate, 10 specimens were cut down, producing the specimen according to the ASTM D256 norm. The samples were impact tested in a PANTEC pendulum with Charpy and Izod configuration. The impact energy was obtained using an $15 \mathrm{~J}$ power hammer for composites with $0,10,20$ and $30 \%$ of fibers. For each volume fraction of fibers, ten specimens were used for statistical validation.The figure 2 show the received and individually separeted Malva fibers.

(A)

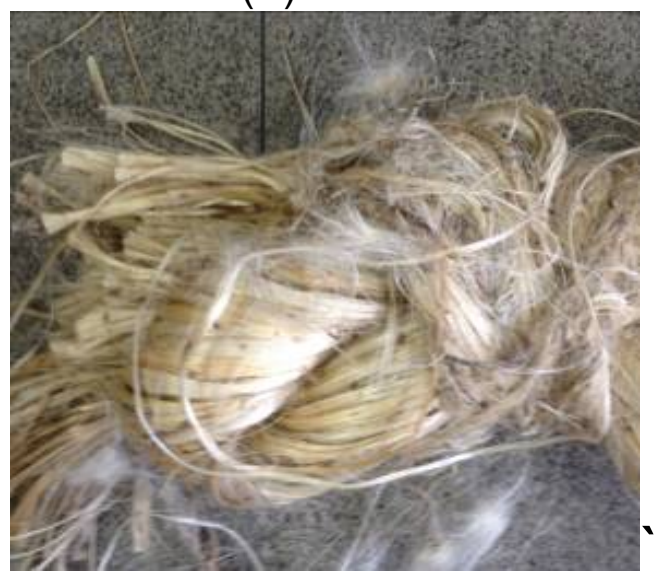

(B)

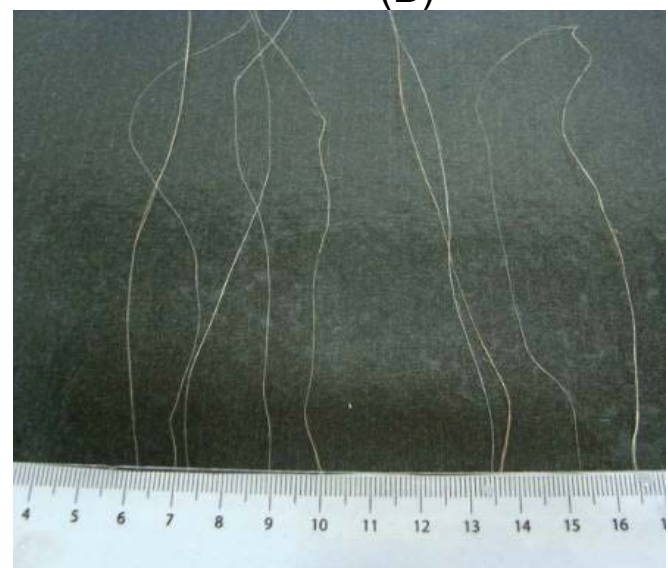

Figure 2 (A) Malva fibers, and (B) Malva fibers individually separated.

\section{RESULTS AND DISCUSSION}

Table I shows the results of the values of Charpy and Izod impact energy with their respective standard deviations for pure epoxy and composites with different volume fractions of malva fibers. 
Table I -Charpy and Izod impact energy for epoxy composites reinforced with malva fibers.

\begin{tabular}{|c|c|c|}
\hline $\begin{array}{c}\text { Fiber Percentage } \\
(\%)\end{array}$ & $\begin{array}{c}\text { Charpy Impact } \\
\text { Energy }(\mathrm{J} / \mathrm{m})\end{array}$ & $\begin{array}{c}\text { Izod Impact Energy } \\
(\mathrm{J} / \mathrm{m})\end{array}$ \\
\hline 0 & $22.9 \pm 9.7$ & $21.8 \pm 9.7$ \\
\hline 10 & $101.1 \pm 28.7$ & $60.2 \pm 14.7$ \\
\hline 20 & $176.6 \pm 41.1$ & $111.9 \pm 23.3$ \\
\hline 30 & $310.2 \pm 98.1$ & $169.4 \pm 29.2$ \\
\hline
\end{tabular}

Based on the results of Table I, the Impact Energy variation as a function of the amount of the different fibers is shown in Figure 3.
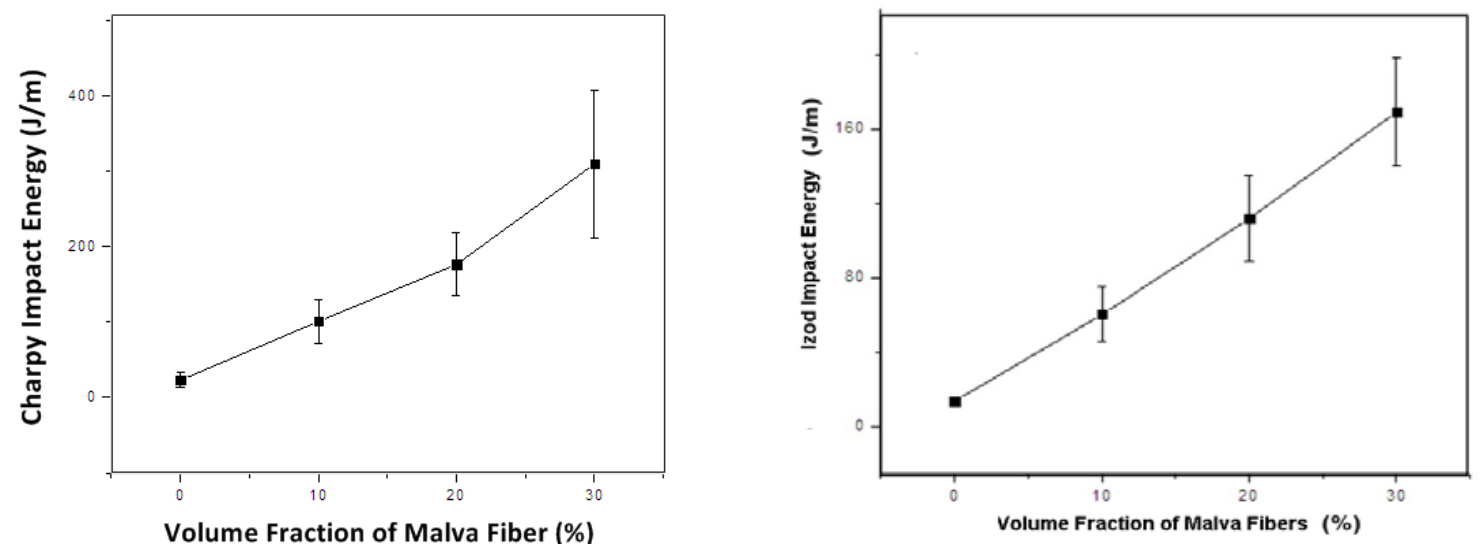

Figure 3 - Charpy and Izod impact energy as a function of the amount of malva fibers.

One should notice the marked increase in Charpy impact energy with the fiber volume fraction of malva. It is also important to note that the error bars present the standard deviation, a common feature for lignocellulosic fibers. This is due to the heterogeneous nature of natural fibers, resulting in substantial dispersion properties of the composites reinforced by them.

In fact as shown in table 2, using long and aligned malva fibers for composites obtains relatively higher impact toughness composites with other fibers too.

\begin{tabular}{c|c|c} 
Table 2 - Comparison on Impact toughness values for different fibers \\
\hline $\begin{array}{c}\text { Composites 30\% } \\
\text { fibers }\end{array}$ & Impact Type & $\begin{array}{c}\text { Impact Tougness } \\
\text { (J/m) }\end{array}$ \\
\hline malva/epoxy & Charpy & 310.2 \\
malva/polyester & Charpy & 716.2 \\
ramie/epoxy & Charpy & 211.7 \\
ramie/polyester & Charpy & 1004.8 \\
coco/polyester & Charpy & 241.2 \\
coco/epoxy & Charpy & 174.7 \\
curaua/polyester & Charpy & 169.7 \\
curaua/epoxy & Charpy & 103.2 \\
\hline
\end{tabular}


It is important to discuss the macroscopic rupture characteristic of the specimens after the test. Figure 4 illustrates the characteristic of rupture of the epoxy specimens for each amount of fiber incorporated. In this figure is shown that the some specimens with $30 \%$ of malva fiber, ie the highest toughness obtained, do not separated into two parts after impact as showed in other work in literature ${ }^{18 .}$ This indicates that cracks nucleated in the notch began to propagate across the brittle epoxy matrix, but when they reach the fiber interface, the crack changes direction.

Specimens with under $20 \%$ malva fiber incorporation undergo complete rupture. Specimens with 30\% malva fibers incorporation, however, did not undergo complete rupture. This leads to the decrease in toughness observed in Figure 4. If all fibers were broken then the energy absorbed would have been even greater ${ }^{19}$. The reason for having a crack nucleated at the notch, changing its trajectory to reach the fibers malva, and going to propagate through the interface with the matrix is due to the low interfacial resistance. This is a consequence of the incompatibility caused by the fact that lignocellulosic fibers are hydrophilic while the polymer matrix is hydrophobic ${ }^{20}$.
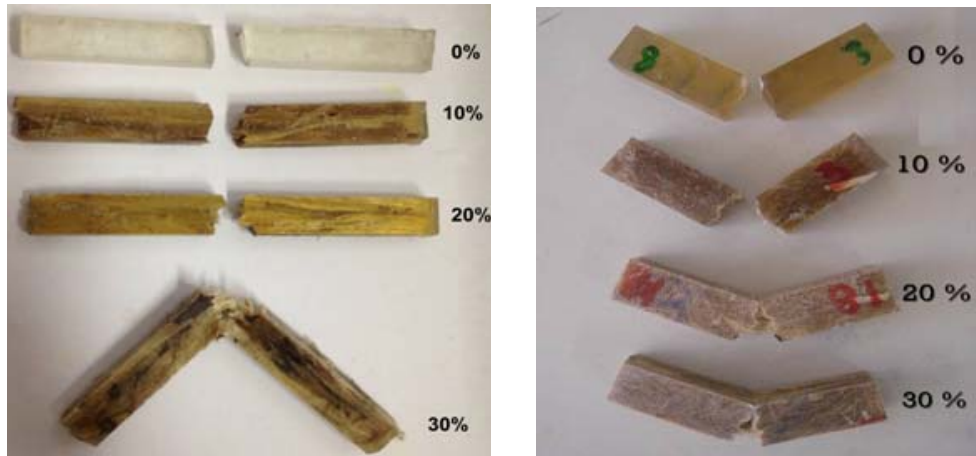

Figure 4 - Specimens typical of malva fiber, broken by Charpy and Izod Impact [21].

Figure 4 shows the macrostructure appearance of the specimens after the Charpy and Izod impact tests for each volume fraction of fibers tested, it should be noticed that with volume fractions greater than $20 \%$ in test of fiber the fracture was not complete and the specimens did not brake, what shows that the impact energy was underestimated and should be higher if the specimens were completely separate.

The SEM analysis of the impact fracture permitted to have a better comprehension of the mechanism responsible for the higher toughness of epoxy composites reinforced with long and aligned malva fibers. Figure 5 shows the aspect of the fracture surface of a pure polyester ( $0 \%$ fiber) specimen ${ }^{21-24}$. With lower magnification, the lighter layer in the left side of the fractograph, Fig 5(A), corresponds to the specimen notch, revealing the machining parallel marks. The smoother and gray layer on the right side corresponds to the transversal fracture surface. The fracture in Fig. 5 suggests that a single crack was responsible for the rupture with the roughness in Fig $5(B)$, being associated with voids and imperfections during the processing. 

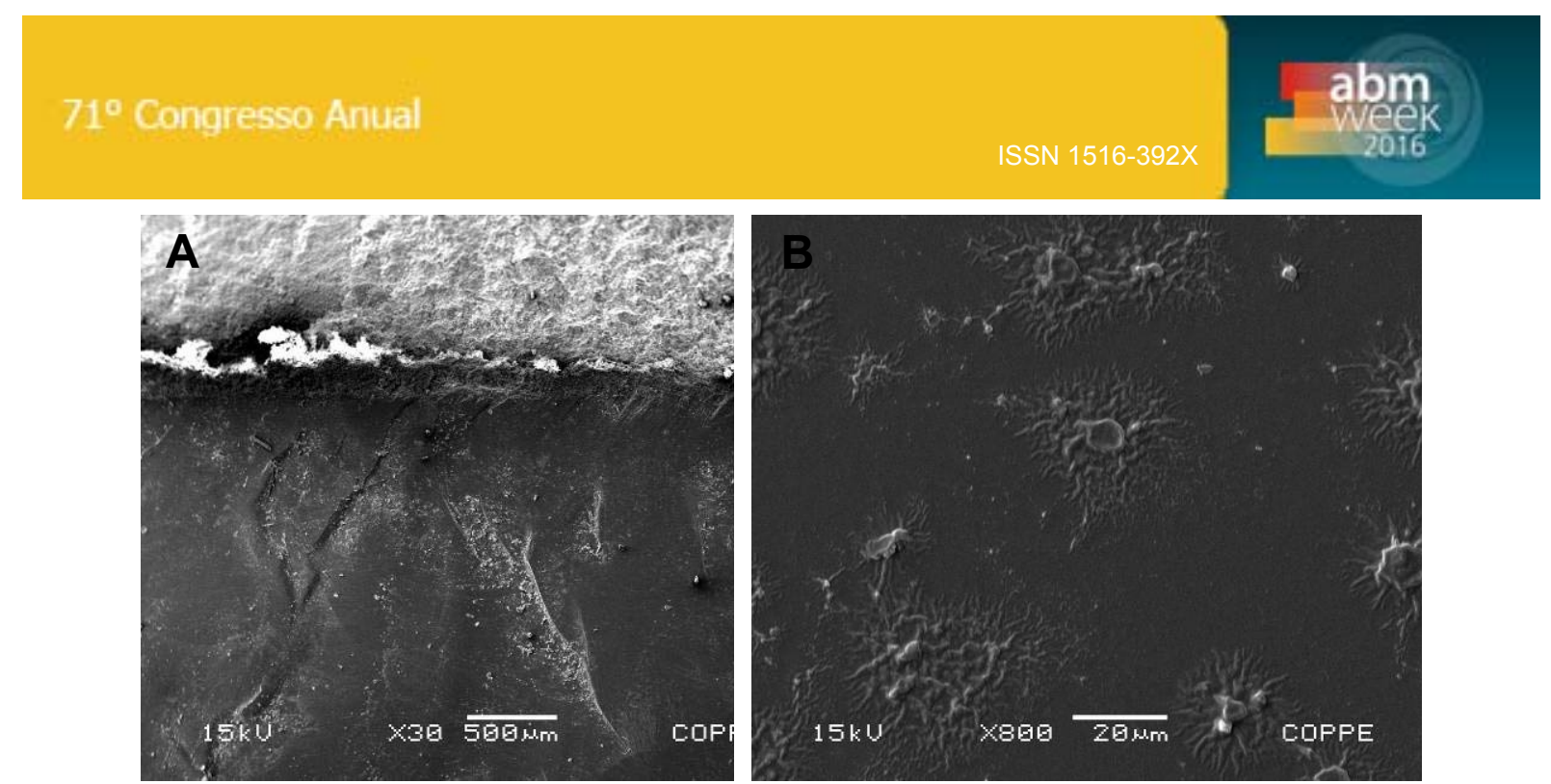

Figure 5 - Fracture surface of the specimen pure epoxy ( $0 \%$ malva fiber): (A) general view with low increase $(B)$ higher increase.

Figure 6 presents details of the impact fracture surface of a epoxy composite specimen with $30 \%$ of malva fiber. This fractograph shows an effective adhesion between the fibers and matrix, where cracks preferentially propagate. Some of the fibers were pulled out from the matrix and others were broken during the impact ${ }^{25-26}$. By contrast, the part of the specimen in which the rupture preferentially occurred longitudinally through the fiber/matrix interface reveal that most of the fracture area is associated with the fiber surface. This behavior corroborates the rupture mechanism of cracks that propagate preferentially in between the malva fiber surface and the epoxy matrix due to the low interfacial strength ${ }^{27}$. The greater fracture area, Fig.6, is associated with increasing amount aligned of malva fibers acting as reinforcement for the composite, that justify the higher impact energy absorbed.

This behavior confirms the mechanism of rupture by cracks that due to the low interfacial shear stress, is preferably spread between the surface of the malva fibers and epoxy matrix as can be seen in Figure $6 \mathrm{~B}^{28}$.

This results in a longitudinal fracture area is relatively large compared to the transverse fracture of the specimens with up to $20 \%$ of malva fiber. Consequently have a higher impact energy to break an area comparatively higher as indicated by Yue ET AL(1995). Similar results were found in polyester matrix composites reinforced with malva fiber. This indicates that the malva fiber provide high tenacity to polymeric matrices reinforced by it.

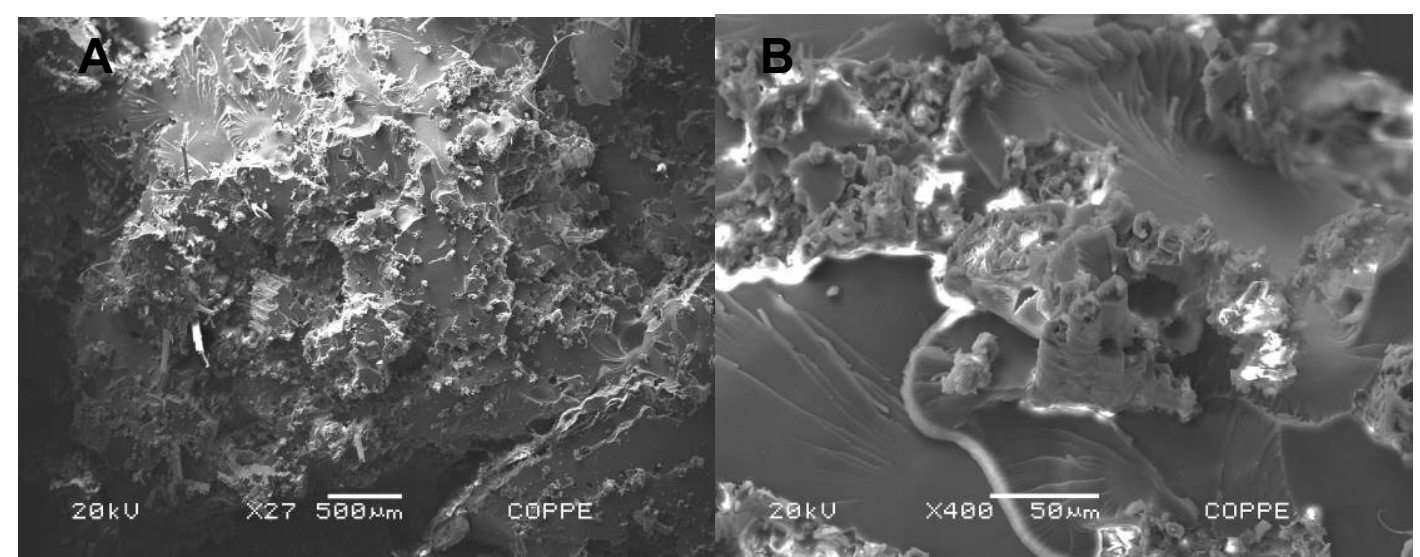

Figure 6 - Fracture surface of the specimen epoxy composite (30\% malva fiber): (A) general view with low increase $(B)$ higher increase. 


\section{CONCLUSIONS}

Composites made of continuous and aligned malva fibers as reinforcement in epoxy matrix, cured at room temperature, show a linear increase in notch toughness, measured in both Charpy and Izod impact tests in relation to the pure epoxy resin.

The incorporation of malva fibers in epoxy matrix improves significantly the toughness of the composite compared to pure epoxy resin.

Along with the retention of some whole malva fibers upon impact, low interfacial tension results in greater energy absorbed in due to the propagation of cracks in the fiber/matrix interface, allowing higher rupture area in relation to a transverse fracture that occurs in the matrix breaking.

The incorporation of volume fractions exceeding $20 \%$ are associated with incomplete fracture of the specimens due to the flexibility of the malva fibers that despite the during the impact tests curving but are not ruptured.

\section{Acknowledgements}

The authors thank the support to this investigation by the Brazilian agencies: CNPQ, CAPES, FAPERJ

\section{REFERENCES}

1 A.K. Bledski and J. Gassan: Composites reinforced with cellulose-based fibers. Prog. Polym. Sci, Vol.4 p.221-274 (1999).

2 A.K. Mohanty, M. Misra and G. Hinrichsen: Biofiber, biodegradable polymers and biocomposites: an overview. Macromol. Mat. Eng. Vol. 276/277 p.1-24 (2000).

3 D. Nabi Sahed and J.P. Jong: Natural fiber polymer composites: a revew. Adv. Polym. Technol. Vol. 18(4), p.351-363 (1999).

4 S.J. Eichhorn, C.A. Baillie, N. Zafeiropoulos, L. Y. Mwaikambo, M.P. Ansell and A. Dufresne: Review - Current international research into cellulosic fibers and composites. J. Mat. Sci. Vol. 36 p. 19-26 (2002).

5 A.K. Mohanty, M. Misra and L.T. Drzal: Sustainable bio-composites from renewable resources: opportunities and challenges in the green materials world. $J$ Polym Environ Vol. 10 p. 19-26 (2002).

6 A.N. Netravali and S. Chabba: composites get greener. Mater Today. Vol. 6 p.22-29 (2003).

7 J. Crocker: Natural materials innovative natural composites. Mater Technol Vol. 2-3; p. 174-178 (2008).

8 M.J. John and S. Thomas: Biofibers and biocomposites. Carbohydr. Polym. Vol. 71; p.343-364 (2008).

9 Kestur G. Satyanarayana, Gregorio G. C. Arizaga, and Fernando Wypych. Biodegradable composites based on lignocellulosic fibers - An overview. Progress in Polymer Sience. Vol. 34 p. 982-1021 (2009).

10 S.N. Monteiro, F.P.D. Lopes, A.S. Ferreira and D.C.O. Nascimento: Natural fiber polymer matrix composites: cheaper, tougher and environmentally friendly. JOM. Vol. 61 p. 17-22 (2009).

11 S.N. Monteiro, F.P.D. Lopes, A.P. Barbosa, A. B. Bevitori, I.L. Silva and L.L. Costa: Natural Lignocellulosic fibers as engineering materials. Metal. Mater. Trans A, Vol. 42 p. 2963-2974, (2011).

12 S. Kalia, B.S. Kaith and I. Kaurs: Cellulose Fibers: Bio and Nano-Polymer Composites . (New York: Springer, (2011).

13 O. Faruk, A.K. Bledski, H.P. Fink and M. Sain: Biocomposites reinforced with natural fibers: 2000-2010. Progress in Polymer Science. Vol.37 p.1552-1596 (2012). 
14 K. G. Satyanarayana; J. L. Guimarães; F Wypych. Studies on lignocellulosic fibers of Brazil. Part I: Source, production, morphology, properties and applications. Composites: Part A, v. 38, p. 1694-1709, (2007).

15 A; Gore An Inconvenient Truth, Uma Verdade Incoveniente, Documentário e Livro, Editora Manole, New York, 328p, (2008).

16 S. P. Campanha Filho, E. Frollini, A. A. S, Curvelo, Organosolo Delignification of Ligonocellulose Materials: Preparation and Characterization of Lignin and Celulose Derivates, São Carlos: Inst de Quim -USP, (1997).

17 K. K. Chawla, Composite Materials Science and Engineering, New York: SpringerVerlag, (1987).

18 A.K.; Bledzki, J, Gassan. Composites reinforced with cellulose-based fibres. Prog. Polym. Sci, v. 24, p. 221-274, (1999).

19 D, Nabi Sahed; J.P.JOG Natural fiber polymer composites: a review, Advances in Polymer Technol., v.18, p. 221-274, (1999).

20 A.K. Mohanty, M Misra, G. Hinrichsen, Biofibres, biodegradable polymers and biocomposites: An overview. Macromolecular Mater. and Eng., v. 276, p.1-24, 2000.

21 J. Crocker, Natural materials innovative natural composites. Materials technology, v.2-3 n. 3 p. 174-178, (2008).

22 S. N. Monteiro.; F.P.D.Lopes, A.S.; Ferreira, D.C.O, Nascimento. Natural fiber polymer matrix composites: cheaper, tougher and environmentally friendly. JOM, v.61, n. 1, p. 17-22, (2009).

23 S.Y. Fu, B. Lauke, E. Mäder, X. Hu and C.Y. Yue, "Fracture resistance of short-glassfiber-reinforced and short-carbon-fiber-reinforced poly-propylene under charpy impact load and dependence on processing", J. Mater. Process. Technol., v.89-90, p.501-507, (1999).

24 S. N. Monteiro, R.C.M.P. Aquino, F.P.D. Lopes, Tenacidade ao entalhe por impacto charpy de compósitos de poliéster reforçados com fibras de piaçava. Rev. Mater., v.11, p.204-210, (2006).

25 S.N. Monteiro, W.P. Inácio, F.P.D. Lopes, Charpy toughness behavior of continuous sisal fiber reinforced polyester matrix composites, In: Mineral, Metals \& Materials Characterization symposium - TMS conference, Seattle, EUA, march, P 1-8, (2010).

26 C.Y. Yue, H.C. Looi, M. Y. Quek, Assessment of Fibre-Matrix Adhesion and Interfacial Properties Using the Pullout Test. Int. J. Adhesion and Adhesives, v. 15, p. 73-80, (1995).

27 S. N. Monteiro, L.L. Costa, F.P.D. Lopes, Characterization of the impact resistance of coir fiber reinforced polyester composites, In: Mineral, Metals \& Materials Characterization Symposium - TMS Conference, New Orleans, LA, USA, Março, , p. 1$6,(2008)$.

28 S. N. Monteiro, D.C.O, Nascimento, L.C. Motta; Characterization of the toughness of piassava fiber reinforced epoxy matrix by izod impact test. In: EPD Congress:

Characterization of Minerals, Metals and Materials - TMS Conference 2009, 2009, San Francisco (CA) USA. Proceedings of the EPD Congress: Characterization of Minerals, Metals and Materials - TMS Conference (2009). 